\title{
Impact of Hormone Replacement Therapy on stroke, and dementia due to Alzheimer's disease on menopausal women
}

Ali Baziad

\begin{abstract}
Abstrak
Akibat kekurangan estrogen pada wanita menopause timbullah berbagai masalah kesehatan. Gangguan susunan saraf pusat seperti stroke dan Alzheimer sering ditemukan pada wanita menopause. Estrogen sangat berperan memicu regulasi pertumbuhan sel-sel neuron dan memiliki juga khasiat sinaptogenik yang meningkatkan fungsi memori. Terapi sulih hormon (TSH) menurunkan risiko stroke hingga 30\% dan mengurangi risiko kematian karena stroke hingga 60\%. Terapi sulih hormon mempengaruhi fungsi memori wanita menopause dan menurunkan risiko timbulnya demensia. Wanita yang mendapatkan TSH menunjukkan peningkatan fungsi memori dan dapat menjawab soal-soal dengan lebih baik dibandingkan wanita yang mendapatkan plasebo. Perdarahan pervaginam merupakan keluhan terbanyak bagi wanita dengan TSH kombinasi. (Med J Indones 2002; 11: 246-9)
\end{abstract}

\begin{abstract}
As a result of estrogen deficiency in menopausal women various health problems occur. Disorders of central nervous system such as stroke and dementia due to Alzheimer's disease are frequently encountered in menopausal women. Estrogen plays an important role in the maintenance of the dense network of neural fibres connecting one nerve cell to another, and in the synaptic activity facilitating cognitive thought and memory. Hormone replacement therapy (HRT) reduced the risk of stroke by $30 \%$ and a reduction of $60 \%$ in risk of stroke mortality. The HRT influence cognitive functioning in menopausal women and may reduce the risk of developing dementia. Women who received HRT performed better on several tests of memory and logical reasoning than women taking placebo. Vaginal bleeding episodes constitute the major cause of women's dissatisfaction with combined HRT. (Med J Indones 2002; 11: 246-9)
\end{abstract}

Keywords: HRT, menopause, memory, cognitive function, vaginal bleeding

Life expectancy rate of women both in Indonesia and in the developed countries continues to improve. In the year 2000, life expectancy rate of Indonesian women is estimated to reach 70 years. Unfortunately, the increase of this life expectancy rate is accompanied by a great variety of health problems. As a result of deficiency in estrogen hormone in menopausal women, disorders of the central nervous system such as stroke, and dementia of Alzheimer's type occurs.

Stroke is the third leading cause of death in women, especially in western country. A 50 year-old - white woman has a $20 \%$ lifetime probability of developing stroke. Stroke is a common disorder with an enormous impact on quality of life. In addition to stroke, dementia due to Alzheimer's disease is also a

Department of Obstetrics and Gynecology, Faculty of Medicine, University of Indonesia/Dr. Cipto Mangunkusumo Hospital, Jakarta, Indonesia common problem in postmenopausal women. The incidence of dementia due to Alzheimer's disease is greater in women than in men. ${ }^{1}$ For instance, in Germany, a million people were found to suffer from Alzheimer's disease, and each year as many as 30,000 - 40,000 cases are encountered. ${ }^{2}$

When a woman suffers from a disorder in the brain, it will be very difficult to cure, and the treatment provided will be of no use any longer. Therefore, the only best way available is prevention. Fortunately, stroke and dementia can be prevented in postmenopausal woman receiving hormone replacement therapy (HRT). ${ }^{1-4}$

This paper was aimed to provide some understanding of the impact of HRT administration on stroke, and dementia due to Alzheimer's disease in menopausal women. 


\section{HORMONE REPLACEMENT THERAPY AND STROKE}

The results of the studies on the relationship of HRT administration and stroke prevention still vary from each other. The Framingham study reported an increased risk of stroke among postmenopausal oestrogen users. ${ }^{5}$ Many other studies revealed either no change or a decrease in the risk with estrogen use. ${ }^{6}$ The European studies showed a significant reduction (30-50\%) in the risk of stroke in women using potent estrogens, and a reduction of $60 \%$ in stroke mortality risk. ${ }^{7}$ In the Swedish study, approximately $33 \%$ of women with combined HRT of estradiol valerate and progesterone showed a reduction in the risk of stroke. ${ }^{8}$ Other studies conducted did not find an increased incidence of stroke and subarachnoidal hemorrhage in HRT administration. ${ }^{9-11}$

\section{HORMONE REPLACEMENT THERAPY AND DEMENTIA}

Dementia due to Alzheimer's disease is accompanied by a disturbance of the cholinergic neurotransmitter system such as asetylcholin and serotonin. ${ }^{12,13}$ Both these neurotransmitters play a vital role for memory and cognitive functioning. Furthermore, pathological speciments taken from dementia patients showed accumulation of toxic proteins in the cerebral cortex, hippocampus, and amygdala. Such protein are known as plaque senilis, a kind of amyloid with beta 44 peptide, consisting of 40 amino acids.

Numerous studies have been conducted to observe the correlation between estrogen administration and the incidence of dementia in post-menopausal women. A case control study demonstrated that long term treatment with estrogen decreased the incidence of dementia until $60 \%$, similar to the decrease of incidence rate of coronary heart disease and osteoporosis. $^{2,14}$ The study performed by National Institute of Neurological and Communication Disorder and Stroke Criteria in Baltimore, USA in 472 postmenopausal women with dementia with and without estrogen administration concluded that estrogen therapy reduced the risk of dementia by 56 $\%$, and women without estrogen therapy were likely to develop dementia 2 to 3 fold. ${ }^{15}$ In the Leisure World Cohort study involving 138 cases, the risk of dementia was less in estrogen users relative to nonusers (RR $0.69,95 \% \mathrm{Cl} \quad 0.46-1.03) .{ }^{14}$ This protective effect became significant with higher dosage and longer duration of HRT. Recently, a prospective cohort study demonstrated that estrogen use may delay the onset and decrease the risk of dementia due to Alzheimer's disease. ${ }^{16}$

\section{ESTROGEN EFFECTS ON BRAIN}

Estrogen can increase blood circulation to the brain. ${ }^{17}$ In women with cerebrovascular disease (transient ischaemic attacks), the use of estrogens increased cerebral blood flow and resulted in better cognitive scores compared to baseline, whereas the results in the non estrogen group became more negative. Quantitative brain blood flow measurement with single photon emission computed tomography demonstrated that estrogen replacement therapy increased total cerebral and cerebral blood flow by $30 \%{ }^{18}$ The ERT affected regional cerebral blood flow on the right parahypocampal, and inferior frontal region. ${ }^{19}$ Both of this brain region have been shown to be involved in memory performance.

Estrogen stimulated the synthesis of neurotransmitter such as acetylcholine and serotonin, which are neurotransmitters for memory and cognitive functioning. ${ }^{17,20}$ In addition to this, estrogen also increased the synthesis of acetylcholine transferase, an enzyme that played a role in the synthesis of acetylcholine in cerebral cortex, stratum basale and hippocampus.

Estrogen plays an important role in the maintenance of the dense network of neural fibres connecting one nerve cell to another, and in the synaptic activity facilitating cognitive thought and memory. The administration of ERT could stimulate neuronal cell growth and had a positive effect on synaptogenesis. Estrogen receptors for the growth of neuron have also been found. Furthermore, estrogen has the inhibitory effect on beta amyloid synthesis in neuronal cells. ${ }^{19}$

\section{HORMONE REPLACEMENT THERAPY REGIMENS AND RECOMMENDED DOSAGES}

Estrogen replacement therapy should be given as early as possible, and continued as long as the women live. ${ }^{21}$ There is a dose and duration effects of estrogen administration, so that the risk of Alzheimer's disease decline with the longer use and higher dose of 
estrogen. The effect of ERT could be seen after 4-5 months of administration. ${ }^{22}$

Table 1. Estrogen dosages recommended for HRT

\begin{tabular}{|c|c|c|}
\hline Estrogen & $\begin{array}{c}\text { Route of } \\
\text { administration }\end{array}$ & Dosage \\
\hline $\begin{array}{l}17 \text { beta Estradiol (progynova }{ }^{\circledR} \text {, } \\
\text { FEM Seven }{ }^{\circledR} \text { ) }\end{array}$ & $\begin{array}{l}\text { Oral } \\
\text { Transdermal } \\
\text { Subcutaneous }\end{array}$ & $\begin{array}{l}1-2 \mathrm{mg} \\
50-100 \mu \mathrm{g} \\
25 \mathrm{mg}\end{array}$ \\
\hline $\begin{array}{l}\text { Conjugated equine estrogen } \\
\text { (CEE) (Premarin } ®, \text { Esthero®) }\end{array}$ & & $0.625 \mathrm{mg}$ \\
\hline Estradiol valerate & & $1-2 \mathrm{mg}$ \\
\hline Estropipete (Ogen $囚)$ & & $0.625-1.25 \mathrm{mg}$ \\
\hline
\end{tabular}

Table 2. Progestogen dosages recommended for HRT, sequentially or continuously

\begin{tabular}{lcc}
\hline \multicolumn{1}{c}{ Progesteron } & Sequentially & Continuously \\
\hline Cyproteron acetate & $1 \mathrm{mg}$ & $1 \mathrm{mg}$ \\
Medroxyprogesterone acetate & $10 \mathrm{mg}$ & $2,5-5 \mathrm{mg}$ \\
$\quad$ Provera ${ }^{\circledR}$, Prothyra ${ }^{\circledR)}$ & & \\
Dydrogesterone (Duphaston $\left.{ }^{\circledR}\right)$ & $10-20 \mathrm{mg}$ & $10 \mathrm{mg}$ \\
Progesteron & $200 \mathrm{mg}$ & $100 \mathrm{mg}$ \\
\hline
\end{tabular}

\section{VAGINAL BLEEDING EPISODES ASSOCIATED WITH COMBINED HRT}

In a patient receiving HRT, both the physician and the patient understand that HRT administration can prevent stroke, dementia, coronary heart disease and bone fracture. However, the compliance rate of use is still low. One of the reasons for this low compliance is the occurrence of vaginal bleeding during the use of HRT. Vaginal bleeding is a common cause of concern and inconvenience to HRT user; it has a major impact on compliance. A high incidence of vaginal bleeding episodes $(50 \%)$ has been observed in many studies of continuously combined HRT. ${ }^{23,25}$ If vaginal bleeding remains the problem, another type of hormone can be administered such as Tibolone (Livial $\left.{ }^{\circledR}\right){ }^{26}$ Tibolone is the type of HRT containing 3 types of hormones, i.e., progesterone, estrogen, and progesterone derivednoretisteron, such that it rarely causes vaginal bleeding.

\section{CONCLUSIONS}

Administration of HRT using estrogen, or combined estrogen and progesterone can reduce the risk of stroke, and dementia due to Alzheimer's disease. The incidence of dementia due to Alzheimer's disease is greater in women. In order to prevent dementia, it is necessary to administer HRT as early as possible for menopausal women. The usual types of estrogen and progesterone used are of natural types. Vaginal bleeding has a major impact on compliance rate. Tibolone is the option for women who do not want vaginal bleeding.

\section{REFERENCES}

1. Scheinder LS. Estrogen replacement in women treated for depression and dementia. In: Brain function and HRT. 8 th International Congress on the Menopause (Abstract). Sydney,Australia, November 6, 1966.p.1.

2. Hesch RD. Estrogen Mangel Risiko Faktor fur den Morbus Alzheimer. In: Fischl FH, Huber JC, editors. Menopause. Wien: Krause \& Pachernberg GmbH; 1995. p.115-9.

3. Ohara $\mathrm{T}$, Isse $\mathrm{K}$, Akazawa $\mathrm{K}$. Longterm estrogen replacement therapy for Alzheimer disease in women. Menopause $1994 ; 1$ : 125.

4. Honyo H, Urabe M, Isawa K. Estrogen treatment for Alzheimer's type. Presentation in symposium Hormone and Brain function in 8 th International Congress on the Menopause. Sydney, Australia, November 6, 1966.

5. Wilson PW, Garisson RJ, Castelli WP. Postmenopausal estrogen use, cigarette smoking, and cardiovascular morbidity in women over 50. New Engl J Med 1985 ;313 : $1038-43$.

6. Grady D, Rubin SM, Petitti DB. Hormone therapy to prevent disease and prolong life. Ann Intern Med 1992 ; $117: 1016-37$.

7. Falkeborn M, Persson I, Terent A, Adami HO, Lithell H, Bergstrom R. Hormone replacement and the risk of stroke. Arch Intern Med $1993 ; 153: 1201-9$.

8. Scherwin BB. Estrogen and/or androgen replacement therapy and cognitive functioning in surgically menopausal women. Psychoneuroendocrinology 1988; 13: 345 - 57.

9. Kuhl H, Schlaganfall. Klimakterium, Postmenopause und Hormonsubstitution. Bremen: Unimed Verlag; 1999.p.107.

10. Stampfer MJ, Colditz GA, Willett WC. Postmenopausal estrogen therapy and cardiovascular disease: ten year follow-up from Nurses' Health Study. N Engl J Med $1991 ; 325: 756-62$.

11. Grodstein F, Stampfer MJ, Manson JE, Colditz GA, Willet WC, Rosner B. Postmenopausal estrogen and progestin use and the risk of cardiovascular disease. $\mathrm{N}$ Engl J Med $1996 ; 335: 453-6$.

12. Whitehouse PJ, Price DL. Alzheimer's disease and senile dementia: loss of neurons in the basal forebrain. Science $1982 ; 215: 1237-9$.

13. Henderson VW. Brain function and HRT. In : Brain function and HRT. 8 th International Congress on the Menopause (abstract). Sydney, Australia, November 6, 1966.p.2.

14. Paganini-Hill A, Henderson VW. Estrogen deficiensi and the risk of Alzheimer' $\mathrm{s}$ disease in women. Am J Epidemiol $1994 ; 140$ : 256 . 
15. Morrison AS. A prospective study of estrogen therapy and the risk of dementia due to Alzheimer's disease. 8 th International Congress on the Menopause (abstract). Sydney, Australia, November 8, 1996.p.3.

16. Henderson VW, Paganini- Hill A, Emanuel CK, Dunn ME, Buckwalter G. Estrogen replacement therapy in older women. Comparison between Alzheimer's disease and nondemented control subjeks. Arch Neurol 1994; 51:896-900.

17. Drachman D. Human memory and regional the cholinergic system. A relationship to aging? Arch Neurol 1974;30:113-21.

18. Ohkura T, Teshima Y, Isse K. Estrogen increases cerebral and cerebellar blood flow in postmenopausal women. Menopause 1995 ;2:13-18.

19. Resnick SM, Maki PM, Golski S, Krat MA, Zonderman AB. Effects of estrogen replacement therapy on PET cerebral blood flow and neuropsychological performance. Horm Behav. 1998; 34:171-82.

20. Hesch RD. The potential influence of estrogen on brain biology and the development of Alzheimer' disease. In: Birkhäush M, Rozenbaum H, editors. Menopause. European Consensus Development Conference. Montreux: ESKA; 1966.p.69-71.
21. Kawas C, Resnick SM, Morrison A. a prospective study of ERT on the risk of developing alzheimer's disease; the Baltimore Longitudinal Study of Aging. Neurology.1997; 48:1517-21.

22. Tang MX, Jacobs D, Stern Y. Effect of oestrogen during menopause on risk and age of onset of alzheimer'disease. Lancet.1996;348:429-32.

23. Mattsson LA, Cullberg G, Samsioe G. Evaluation of continuous oestrogen-progestogen regimen for climacteric complaints . Maturitas 1982;4:95-102.

24. Magos AL, Brincat M, Studd JW, Wardle P, Schlesinger P, O'Dowd T. Amenorrhea and endometrial atrophy with continuous oral estrogen and progestogen therapy in postmenopausal women. Obstet Gynecol 1985;65:496-9.

25. Weinstein L, Bewtra C, Gallagher JC. Evaluation of continuous combined low-dose regimen of estrogenprogestin for treatment of the menopausal patient. Am J Obstet Gynecol 1990;162:1534-9.

26. Staland B. Continuous treatment with natural oestrogen and progestogens. A method to avoid endometrial stimulation . Maturitas 1981;3:145-56. 